\title{
THE WOOD STRUCTURE OF DICRANOSTYLES (CONVOLVULACEAE)*
}

\author{
ALBERTA M. W. MENNEGA \\ Botanisch Museum en Herbarium, Utrecht
}

\section{SUMMARY}

The anatomy of the mature wood of three species of the South American genus of woody climbers Dicranostyles Bth. is described and compared with that of the secondary wood of other genera of the Convolvulaceae. The stems are characterized by the occurrence of concentric rings of included phloem tissue. In most characters the three species are quite similar, except for the absence of rays over two cells wide in $D$. guianensis. Instead of these, aggregate rays occur at intervals between consecutive rings of included phloem. $D$. mildbraediana possesses fibre tracheids with next to the normal large bordered pits numerous very large irregular slits giving the impression of a helical sculpturing of the walls. From a comparison with other Convolvulaceous genera like Bonamia, Ipomoea, Maripa, Neuropeltis, and Prevostea ${ }^{1}$ it appears that nearest to Dicranostyles in general appearance as well as in anatomical structure is the genus Maripa. The resemblance to Ipomoea seems only superficial. The relation between anatomical conformities of genera and their position in the various systems of subdivision of the family is discussed.

\section{INTRODUCTION}

In the course of a study of a collection of woody climbers gathered in Suriname by Dr. J. van Donselaar some difficulties arose over two stems with concentric bands of included phloem. Though the wood structure as seen with a hand lens was reminiscent of Moutabea and Securidaca, the sterile or, respectively, fruiting herbarium vouchers excluded Polygalaceous relationship. As described elsewhere (MENNEGA 1968) these herbarium specimens were eventually identified as species of Dicranostyles, a genus of Convolvulaceae hitherto unknown from Suriname. It turned out that the wood structure is in agreement with some other genera of this family.

\section{LITERATURE}

In his treatment of lianas with abnormal secondary growth PFeIfFer (1926) mentions 12 genera of Convolvulaceae with the concentric type of included phloem, in his terminology "corpus lignosum circumvallatum". Dicranostyles is not among these. Earlier SCHENK (1893) studied mature wood of lianas, chiefly from South Brazil. Argyreia, Convolvulus, Ipomoea and Porana, an

- Dedicated to Professor Dr. C. E. B. Bremekamp.

1 Though Prevostea is a synonym of Calycobolus (HeINE 1963) the name Prevostea will still be used in the present paper to follow the current anatomical literature. 
Asiatic taxon, are cited by him as genera in which successive bundles of interxylary phloem occur. On the basis of his own investigations he described and illustrated more fully Ipomoea violacea and I. umbellata (a synonym for Merremia umbellata (Mey) Hall.f.) and a sample of Porana. In both species of Ipomoea the $3 \mathrm{~cm}$ thick stems are deeply tri-sulcate. In the same year H. HALLIER (1893) published his extensive and very thorough studies of the Convolvulaceae, in which are included their anatomy, morphology, and pollen structure. His division of the family is based on the results of these ample investigations. Not having material at hand of larger-sized stems his remarks on the anatomy of Dicranostyles, and the closely related genus Lysiostyles, were bound to be rather scanty. He reported the occurrence of intraxylary phloem, a general feature of the subfamily Convolvuleae, the large size and the simple perforations of the vessels, and the presence of fibre-tracheids with large bordered pits. SOLEREDER (1899) based his account of this family chiefly on Hallier's paper, and in Metcalfe \& Chalk's Anatomy of the Dicotyledons (1950) it is stated that not much additional information on wood anatomy is available. Particularly for Dicranostyles the data are very scarce. Earlier CHaLK \& ChatTaway (1937) did not include the Convolvulaceae in their paper on woods with included phloem. More recently Miss OBaton (1960) published a study on the wood of lianas from West Africa with abnormal secondary growth. Three genera of $C$. are treated: Bonamia, Neuropeltis and Prevostea. In none of them the circummedullary type of included phloem occurs.

\section{MATER I A L}

The specimens of Dicranostyles and of some other species investigated for this study are listed below.

\begin{tabular}{|c|c|c|c|c|}
\hline Name & Wood No. & Locality & Collector & Diam. \\
\hline Bonamia maripoides Hall. f. & Uw 11753 & Venezuela & Breteler 3747 & $\begin{array}{l}1,3,3 \times 5.5 \\
\mathrm{~cm}\end{array}$ \\
\hline Bonamia maripoides Hall. $\mathrm{f}$. & Uw 11761 & Venezuela & Breteler 3761 & $3 \mathrm{~cm}$ \\
\hline Bonamia maripoides Hall. f. & Uw 12126 & Suriname & v. Donselaar 3510 & $1.8 \mathrm{~cm}$ \\
\hline Calycolobus (Prevostea) spec. & Uw 9342 & Cameroun & Breteler 1568 & $2.5 \mathrm{~cm}$ \\
\hline Calycolobus spec. & Uw 9455 & Cameroun & Breteler 2088 & $4 \mathrm{~cm}$ \\
\hline $\begin{array}{l}\text { Calycolobus mortehanii (de Wild.) } \\
\text { Heine }\end{array}$ & Uw 9422 & Cameroun & Breteler 1829 & $3.5 \mathrm{~cm}$ \\
\hline $\begin{array}{l}\text { Dicranostyles guianensis } \\
\text { A. Mennega }\end{array}$ & Uw 11866 & Suriname & v. Donselaar 2457 & $4 \mathrm{~cm}$ \\
\hline $\begin{array}{l}\text { Dicranostyles mildbraediana } \\
\text { Pilger }\end{array}$ & Uw 14508 & Peru & $\begin{array}{l}\text { Tessmann } 4069 \\
\text { (type, BFA 2744, } \\
\text { Reinbek) }\end{array}$ & - \\
\hline $\begin{array}{l}\text { Dicranostyles villosa Ducke var. } \\
\text { polasiocalyx A. Mennega }\end{array}$ & Uw 1874 & Suriname & $\begin{array}{l}\text { Lanjouw \& } \\
\text { Lindeman } 2667\end{array}$ & $2 \mathrm{~cm}$ \\
\hline$I$ moea murucoides $\mathrm{R}$. et $\mathrm{S}$. & Uw 14726 & Mexico & $\begin{array}{l}\text { Iltis, Koeppen, } \\
\text { Iltis } 816\end{array}$ & $15 \mathrm{~cm}$ \\
\hline Maripa cf. glabra Choisy & Uw 12014 & Suriname & v. Donselaar 3122 & $4.5 \times 5 \mathrm{~cm}$ \\
\hline 174 & & & a Bot. Neerl. & 1), Febr. I \\
\hline
\end{tabular}




\begin{tabular}{|c|c|c|c|c|}
\hline Name & Wood No. & Locallity & Collector & Diam. \\
\hline $\begin{array}{l}\text { Maripa reticulata Ducke } \\
\text { Maripa scandens Aubl. }\end{array}$ & $\begin{array}{l}\text { Uw } 11880 \\
\text { Uw } 2687\end{array}$ & $\begin{array}{l}\text { Suriname } \\
\text { Brazil }\end{array}$ & $\begin{array}{l}\text { v. Donselaar } 2792 \\
\text { Ducke } 273 \text { (Yale } \\
\text { 32649) }\end{array}$ & $\begin{array}{l}4 \times 6 \mathrm{~cm} \\
-\end{array}$ \\
\hline $\begin{array}{l}\text { Maripa scandens Aubl. } \\
\text { Maripa violacea (Aubl.) v. Ooststr. } \\
\text { Neuropeltis acuminata Bth. } \\
\text { Neuropeltis acuminata Bth. } \\
\text { Neuropeltis velutina Hall. f. }\end{array}$ & $\begin{array}{l}\text { Uw } 11882 \\
\text { Uw } 2199 \\
\text { Uw } 9336 \\
\text { Uw } 9386 \\
\text { Uw } 9344\end{array}$ & $\begin{array}{l}\text { Suriname } \\
\text { Suriname } \\
\text { Cameroun } \\
\text { Cameroun } \\
\text { Cameroun }\end{array}$ & $\begin{array}{l}\text { v. Donselaar } 2806 \\
\text { BBS } 15 \\
\text { Breteler } 1547 \\
\text { Breteler } 1700 \\
\text { Breteler } 1577\end{array}$ & $\begin{array}{l}3.5 \mathrm{~cm} \\
3.5 \mathrm{~cm} \\
3,6.5 \mathrm{~cm} \\
3.5 \mathrm{~cm} \\
3.5 \mathrm{~cm}\end{array}$ \\
\hline
\end{tabular}

\section{ANATOMY}

\subsection{The wood structure of Dicranostyles}

In he following generic description the first-formed secondary xylem is left out of onsideration, as in a ring of about $1-1.5 \mathrm{~mm}$ around the pith the structure of he wood is completely different from the parts formed afterwards.

Stems on cross section with a round outline, the pith often more or less excentric, clearly visible. The bark rather thin, patchy, yellowish brown, longitudinally superficially fissured. The wood yellowish brown, hard, characterized on cross section by large, mostly solitary vessels and by narrow concentric bands of included phloem, the bands slightly darker than or of the same colour as the wood.

\section{Microscopic structure:}

Vessels: Mostly solitary, few in tangential or radial pairs, scattered, on the average 3.5-5 (1-10) per sq. $\mathrm{mm}$; round in cross section; diameter highly variable, from $50-360 \mu$, with a preponderance of $240-300 \mu$; length of vessel elements between $300-650 \mu$; perforations simple, horizontal in the wide vessels, slightly oblique in the narrow ones; wall $3-4 \mu$ thick; intervascular pits alternate, rounded, the apertures extending to the borders $12-20 \mu$ wide; thin-walled tyloses frequent (figs. 1,6).

Tracheids: Usually present, not numerous, often with one-sided perforations; of the same length as the vessel members.

Fibre tissue: Composed of fibre tracheids with numerous large bordered pits with crossed apertures on radial and tangential walls; diameter from $20-36 \mu$, the walls $4-6 \mu$ thick; on the average $1000(650-1200) \mu$ long in D. mildbraediana and $D$. villosa, $700(500-1000) \mu$ in D. guianensis; the ends of rather variable shape; the pits $8-9 \mu$ wide in $D$. guianensis, and $D$. villosa, $16 \mu$ in $D$. mildbraediana; in all species round apertures $6-12 \mu$ wide may be present in variable numbers on the radial walls (figs. 4,6 ). A peculiarity of $D$. mildbraediana are the numerous irregular slits in the walls giving the impression of helical sculpturing ( figs. 3, 4).

Rays: Of two sizes and heterocellular. The uniseriates generally composed of square and upright cells, $1-15$ cells high (up to $700 \mu$ ), 15-20 $\mu$ wide. The multi- 

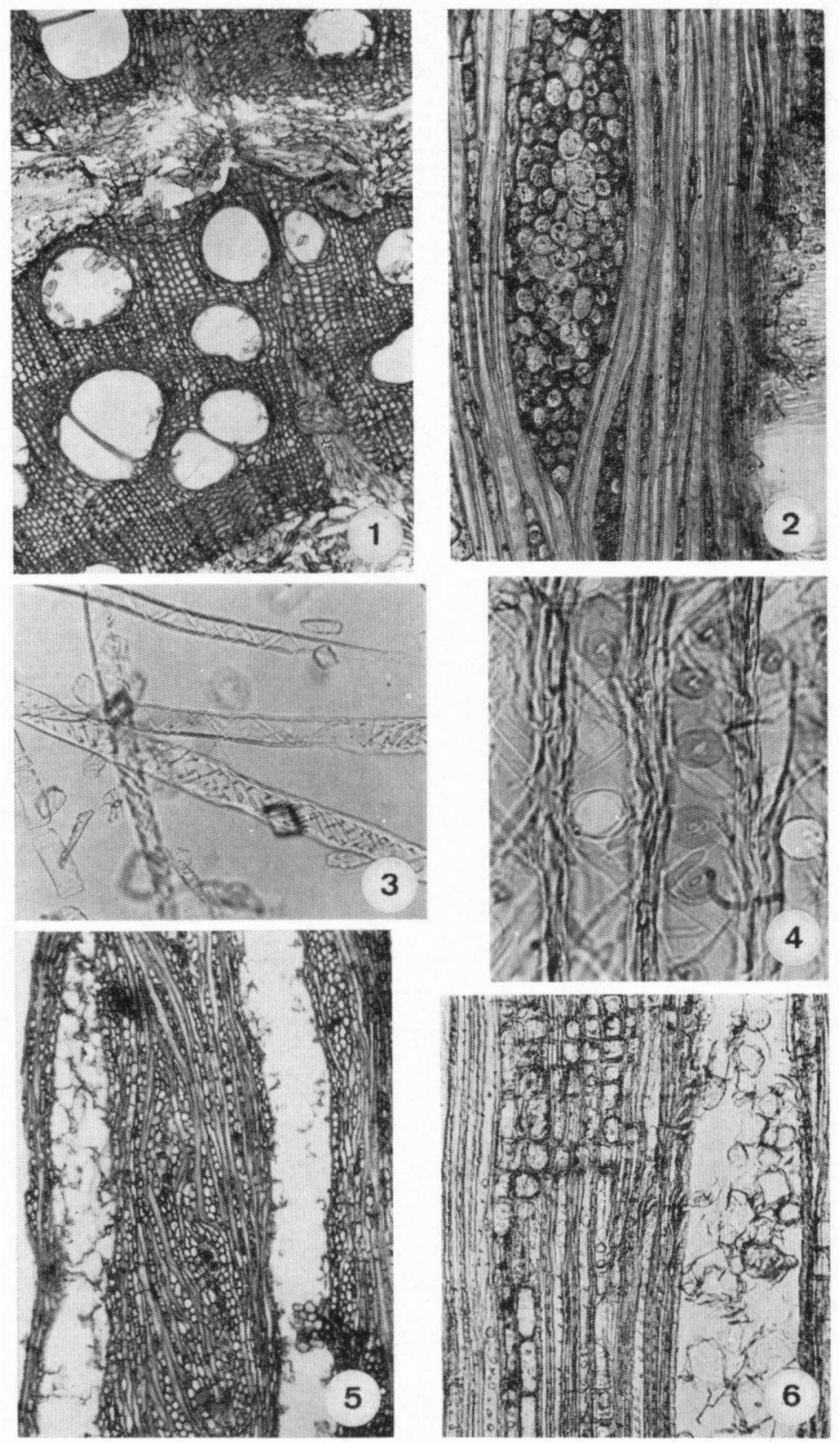

Fig. 1, 2. Dicranostyles villosa var. lasiocalyx (Uw 1874) transv. sect. $33 \times$; tang. sect. $80 \times$. Fig. 3. 4. D. mildbraediana (Uw 14508) macerated fibres, $80 \times$; fibres, rad. sect. $325 \times$. Fig. 5, 6. D. guianensis (Uw 11866) aggregate ray, tang. sect. $33 \times$; rad. sect. $80 \times$. 
seriates 2 cells wide in $D$. guianensis, $4-8$ cells in $D$. villosa, and $D$. mildbraediana (figs. 2, 5), the uniseriate margins few to several cells high, most of the cells of the multiseriate parts square, height of the multiseriate part up to 55 cells $(1750 \mu)$. Pits to vessels large, roundish or ovate. Rhombic crystals present in the wide rays, particularly where those are in contact with the bands of included phloem, in these places ray cells often transformed into stone cells (fig. 1 ).

In $D$. guianensis instead of wide rays aggregate rays composed of rays and fibres, in the other species the wide rays often obliquely dissected by some fibres. Number 7-10 per $\mathrm{mm}$, of which 0-2 wide or aggregate rays.

Parenchyma: Apotracheal and paratracheal; predominantly in very irregular short to rather long apotracheal bands of variable width, often on the adaxial side in contact with the vessels and sometimes in a narrow vasicentric ring; strands of $2-4$ cells in $D$. guianensis and $D$. villosa, up to 8 cells in $D$. mildbraediana; the cells $20 \mu$ wide tangentially, $60-80(100) \mu$ high.

Interxylary phloem: In concentric bands, the bands slightly undulating, and each band of variable width, on the average $500 \mu$ wide $(200-1000 \mu)$; sometimes anastomosing or with dead ends, in places radially connected by strands composed of fiores, and multiseriate rays (fig. 1).

Sclerotic cells or groups of these cells often present in the connecting strands and on the abaxial sides of the phloem bands, here also rhombic crystals and in D. mildbraediana druses.

\subsection{General remarks on the structure of the wood}

As the species proved to be rather similar in their microscopic structure a generic description seemed adequate.

The most remarkable feature which distinguishes $D$. mildbraediana from the other species is the peculiar structure of the fibre walls (figs. 3, 4). Perhaps this is what HaLliER (p. 503) observed and described for the wood fibres of Erycibe micrantha and Prevostea spectabilis (a synonym of Bonamia maripoides) as holes and cavities in the fibre wall. (In material of the latter species studied by me such fibres were not observed). These fibre-tracheids resemble more or less the spiral cells of the parenchyma of Ancistrocladus as figured in GoTTWALD \& PARAMESWARAN's paper (1968).

D. guianensis differs by the absence of wide rays.

Other peculiarities like the wide round pores in the radial walls of the fibre tracheids and the very large intervascular pits are as far as can be judged from a sketchy examination of material of other genera (see the next paragraph), of more general occurrence and rather characteristic for the Convolvulaceae.

\subsection{Other genera}

The woody genera represented in South America beside Dicranostyles are Bonamia, Convolvulus, Exogonium, Ipomoea, Maripa, Merremia and Calycobolus (syn. Prevostea). Material was available of Bonamia maripoides, Ipomoea murucoides, Maripa (four species). Of those species the material of Maripa showed the closest resemblance to the woods of Dicranostyles in general appearance as 
well as in microscopic characters. The chief differences are the occurrence of thick instead of thin tyloses, and the lack of wide rays in Maripa.

Concentric rings of included phloem also occur in Ipomoea, as stated before, and this could be confirmed by a study of the wood of $I$. murucoides, a small tree. Here, however, the resemblance is more superficial. The widest vessels $(160 \mu)$ are arranged in a ring on the adaxial sides of the phloem bands, the intervascular pits are at most $15 \mu$ wide; the fibre tissue is composed of extremely thin-walled short fibres with few bordered pits and more numerous simple pits on their radial walls; the ray tissue consists of 1 -seriate and numerous 2-7-seriate rays; parenchyma is restricted to a few paratracheal cells; connective strands are absent. To what degree the arborescent habit of this species is of influence on the structure of the elements is difficult to assess. It would be interesting to investigate wood of climbing species for comparison. From the pertinent literature no detailed references on the microscopic structure are available.

In Bonamia maripoides, Neuropeltis (from Africa) and Prevostea spec. (Africa) the abnormity of the wood is different. In young stems of Bonamia and in Neuropeltis the phloem forms wedges in the woody cylinder, Pfeiffer's "corpus lignosum interruptum". In older, thick stems of $B$. maripoides the pattern of the wood and the included phloem becomes far more complicated and different from woods of Neuropeltis. Species of Prevostea, as described by Obaton and confirmed by material seen by myself, are characterized by stems with dispersed woody cylinders, Pfeiffer's "corpus lignosum diffractum". Here, too, the elements show the same characteristic features, like wide vessels, large intervascular pits, fibre-tracheids with large bordered pits and circular pores on their radial walls as seen in Dicranostyles and Maripa.

\section{DISCUSSION}

From the foregoing we may conclude that the wood of Dicranostyles is more similar to Maripa than to any of the other genera investigated. This is not in agreement with the taxonomic position of Dicranostyles according to Hallier's system. Here we find in the tribe Dicranostyleae the genera Prevostea, Bonamia, Neuropeltis, Dicranostyles, Lysiostyles, and 6 other genera, mostly herbs or small shrubs; but Maripa in the tribe Erycibeae. Both tribes belong to his subdivision Psiloconiae, characterized by smooth pollen whereas Ipomoea belongs to the Echinoconiae with spinulose pollen. Nearly the same subdivision of the family is accepted by VAN OOSTSTROOM (1953) in his revision of the Malesian taxa, except that Dicranostylinae are treated as a subtribe of Convolvuleae of the subfam. Convolvuloideae. PETER (1897) treated the family in 1891 for Engler \& Prantl, but it did not appear in Vol. IV, 3a of that work until 1897. Here, too, Dicranostyles is placed in a tribe Dicranostyleae with the same genera as enumerated above, whereas Maripa is placed in the subtribe Argyreiinae of the Convolvuleae, and Ipomoea in the subtribe Convolvulinae. In the 1964 edition of Engler's Syllabus the genus Dicranostyles is to be found under the tribe Argyreieae; Prevostea under the tribe Poraneae; Bonamia and Ipomoea in the Con- 
volvuleae. (Maripa and Neuropeltis are not mentioned.) ROBERTY (1952) in his Genera Convolvulacearum recognizes a new subfamily Argyreioideae with 3 tribes. One of these is the tribe Lysiostyleae including the genera Lysiostyles, Dicranostyles, Maripa and Mouroucoa. The last-named genus consists of a number of species formerly included in Maripa. With regard to this last rearrangement no conclusion can be drawn from wood anatomy, but the grouping of Dicranostyles with Maripa in one tribe is supported by the results of this study.

From the brief investigations of woods of Bonamia, Neuropeltis and Prevostea (see also Obaton's paper) I would suggest that each of them is of a different structure. In Roberty's system Bonamia belongs in the subfamily Convolvuloideae, tribe Cresseae, but Neuropeltis and Prevostea in separate tribes of the Poranoideae.

\section{ACKNOWLEDGEMENT}

The author is much indebted to Mrs. J. Koek-Noorman for her assistance with the micro-photographs, to Miss M. Maten for the preparation of the sections, and to Dr. K. U. Kramer for his correcting of the English text. Thanks are also due to Messrs. F. Breteler (Wageningen), $H$. Gottwald (Reinbek) and H. Iltis \& R. Koeppen (Madison) who provided me with valuable specimens.

\section{REFERENCES}

Chalk, L. \& M. M. Chattaway (1937): Identification of woods with included phloem. Trop. Woods no. 50: 1-31.

GotTwald, H. \& N. Parameswaran (1968): Das sekundare Xylem und die systematische Stellung der Ancistrocladaceae und Dioncophyllaceae. Bot. Jb. 88: 49-69.

Hallier, H. (1893): Versuch einer natürlichen Gliederung der Convolvulaceae auf morphologischer und anatomischer Grundlage. Engler's Bot. Jhb. 16: 453-591.

HeINe, H. (1963): The genus Calycobolus Willd. ex Roem. \& Schultes (Convolvulaceae) in Africa. Kew Bull. 16: 387-391.

MenNegA, A. M. W. (1968): On two new species and one new variety of Dicranostyles (Convolvulaceae) collected in the Guianas and Amazonia. Proc. Kon. Ned. Akad. Wet. (Amsterdam) Ser. C, $71: 550-557$.

MetCalfe, C. R. \& L. ChalK (1950): Anatomy of the Dicotyledons. Oxford.

OBATON, M. (1960): Les lianes ligneuses à structure anormale des forêts denses d'Afrique occidentale. Thèse, Paris.

Ooststroom, S. J. van (1953): Convolvulaceae In Flora Malesiana Ser. 1, vol. 4: 388-513.

Peter, A. (1897): Convolvulaceae. In Engler \& Prantl, Die natürlichen Pfanzenfamilien, IV, 3a: 1-40. Leipzig.

Pfeiffer, H. (1926): Das abnorme Dickenwachstum. In K. LinsBauer's Handbuch der Pflanzenanatomie 9. Berlin.

RoBerTy, G. (1952): Genera Convolvulacearum. Candollea 14: 11-61.

SCHENK, H. (1893): Beiträge zur Biologie und Anatomie der Lianen, Teil II. In A. F. W. SCHIMPE, Botanische Mitteilungen aus den Tropen Heft 5, II. Jena.

SCHLEPEGRELL, G. vON (1892): Beiträge zur vergleichende Anatomie der Tubifloren. Bot. Centr. bl. 49: 259, sqq.

SOLEREDER, H. (1899): Systematische Anatomie der Dicotyledonen. Stuttgart. 